\begin{tabular}{|l|l|l|}
\hline \multicolumn{2}{|c|}{ PublisherInfo } \\
\hline \hline PublisherName & $:$ & BioMed Central \\
\hline \hline PublisherLocation & $:$ & London \\
\hline \hline PublisherImprintName & $:$ & BioMed Central \\
\hline \hline
\end{tabular}

\title{
Of mice and mitochondria
}

\begin{tabular}{|l|c|l||}
\hline \multicolumn{2}{|c|}{ ArticleInfo } \\
\hline \hline ArticleID & $:$ & 4778 \\
\hline \hline ArticleDOI & $:$ & $10.1186 /$ gb-spotlight-20030522-01 \\
\hline \hline ArticleCitationID & $:$ & spotlight-20030522-01 \\
\hline \hline ArticleSequenceNumber & $:$ & 130 \\
\hline \hline ArticleCategory & $:$ & Research news \\
\hline ArticleFirstPage & $:$ & 1 \\
\hline \hline ArticleLastPage & $:$ & 2 \\
\hline \hline & & RegistrationDate : 2003-5-22 \\
\hline ArticleHistory & $:$ & OnlineDate \\
\hline \hline ArticleCopyright & $:$ & BioMed Central Ltd2003-5-22 \\
\hline \hline ArticleGrants & $:$ & \\
\hline \hline ArticleContext & $:$ & 130594411 \\
\hline \hline
\end{tabular}




\section{Cathy Holding}

Email: cholding@hgmp.mrc.ac.uk

Mitochondrial DNA mutates at a faster rate than nuclear genomic sequences and may provide a mechanism for organisms to adapt rapidly to a changing environment. Mitochondrial proteins interact with gene products encoded by the 'host' nucleus to carry out oxidative phosphorylation, and selection pressure may cause these interactions to work at maximum efficiency under different conditions. Comparative analysis of mitochondrial DNA sequences has been used to discover phylogenetic and phylogeographic patterns in a number of organisms. In the May 22 issue of Nature, Oliver Pergams and colleagues at the University of Illinois use these techniques to detect possible variations in the conditions in which an organism is living (Nature, 423:397, May 22, 2003).

Pergams et al. obtained specimens of skin of the white-footed mouse, Peromyscus leucopus, from museums worldwide. They obtained 61 samples originally collected from five different areas in Chicago and compared a 340bp polymorphic region in the cytochrome oxidase II gene with samples collected in modern-day Chicago. They identified three haplotypes, named $A, M$, and $M w$, and found a decrease in the proportion of $A$ at each geographic location, with $5 / 5$ in 1850-1899, 18/30 in 1900-1949, 4/73 in 1950-1999, and none in the present day samples. Although none of the four base changes between the $A$, $M$ and the $M w$, haplotypes causes an amino acid change in the protein, it is possible that conditions within the mitochondrion may account for a change in advantage of a particular sequence.

"The genotype most common 100 years ago is now extremely rare, indicating that the mammalian mitochondrial genome can undergo rapid evolution," the authors state. "We suggest that the $M$ haplotype has not only spread through the white-footed mouse population but might also have contributed to the displacement of the prairie deer mouse by the white-footed mouse," they conclude.

\section{References}

1. The mitochondrial genome: mutation, selection and recombination.

2. The function of genomes in bioenergetic organelles.

3. Nature, [http://www.nature.com/nature]

4. University of Illinois, [http://www.uic.edu/]

This PDF file was created after publication. 